all the essential knowledge and up-to-date information lucidly written with ample reference to methods of tracing of contacts, public health problems and the control of tuberculosis as a national and world-wide problem.

One of the most attractive aspects of the book is the recognition paid in almost every chapter to the history of medicine. Each subject is introduced with a brief account of the development of our knowledge from early times up to the present day, an approach which, cumulatively, gives the student a wide insight into disease processes and their treatment. There is a small and up-to-date bibliography at the end of each chapter for those who are interested in reading for themselves the original works which have resulted in the sum total of our medical knowledge.

The paper and binding are best described as handsome. The printing and arrangement are quite irreproachable and the illustrations, diagrams and reproduced $X$-rays and photographs are almost always clear and usually add to the understanding of the text. Though this is a valuable book on a consultant's desk it is perhaps the best single volume textbook that exists for the practitioner. Its one real drawback is its price.

\section{A SHORT TEXTBOOK OF RADIOTHERAPY FOR TECHNICIANS AND STUDENTS}

By J. WALTER, M.A., B.M., M.R.C.P., D.M.R.E., and H. Miller, M.A., Ph.D., F.Inst.P. Pp. xii +444 , with 199 illustrations. London : J. \& A. Churchill. I950. 28s.

This book fulfils a definite need and deserves to be widely used. It is well produced and has a large number of good illustrations. Written primarily for radiographers whose needs are constantly kept in mind, it should also find a wider circle of readers. House surgeons to radiotherapeutic departments, surgeons and physicians who are interested in radiotherapy will find much helpful information. The authors have taken great trouble in explaining the meaning of terms they use and even give the derivation of medical words. It does, however, contain rather too much for the student radiographer to digest without help, and in order to understand the intricacies of radiation therapy fully it should be supplemented by lectures of the right type.

The structure of matter and the physical properties of $X$-rays and radioactive materials are dealt with in the first part of the book as well as the biological effects of radiation. Two chapters are devoted to the methods of applying $\mathrm{X}$-rays and radium, followed by an excellent chapter on dosage and the principles of treatment. A few of the important malignant and non-malignant lesions are discussed and the various techniques used in their treatment by radiation are described and well illustrated. As it states in a very disarming preface, the wide difference in modern techniques and also in the education and training of radiographers makes it impossible to please all. However, the methods described in this book are up to date and are those used in many of the best centres.

The modern clinician who wishes to read a short textbook on this subject could not do better than get this book.

E.L.G.H.

\section{SCHISTOSOMIASIS IN SOUTH CENTRAL AFRICA}

By Michael Gelfand, M.D., M.R.C.P. Pp. 239. London : H. K. Lewis. Cape Town : The Post-Graduate Press by Juta \& Co. Ltd. 1950. 25s.

This is a valuable monograph for all those working on schistosomiasis by the author of that interesting book 'The Sick African.' Like most monographs the inevitable repetition does not lead to easy reading, but the author has summarized his conclusions at the end of each chapter adequately and well.

Dr. Gelfand's findings differ from those of previous workers in Egypt. $\mathrm{He}$ is in the fortunate position of having ready access to all the pathological material submitted to the Salisbury laboratory, and being able to compare the findings in Europeans and Africans.

He employed the digestion technique in 4 per cent., caustic potash for rectal and vesical biopsy snippings and extended it to all post-mortem material. He shows that multilobar cirrhosis of the liver is no commoner in endemic than in non endemic areas where the same dietary deficiencies operate, and he is sceptical about the role bilharziasis plays in the aetiology of cancer of the bladder and rectum, basing his conclusions on the fact that in Salisbury, Rhodesia, the incidence of bladder cancer is higher in Europeans than Africans, whilst the bilharzial incidence is as 1 to $4 \cdot 3$.

Dr. Gelfand calls his monograph a clinicopathological study, but surely in as extensive a monograph as this the question of treatment should be included. There are one or two curious omissions, no word is mentioned of the value of prostatic massage prior to the passage of urine to increase the chances of finding schistosome eggs, a method most pathologists have found of help in European cases where the infection is light, and no mention is made of the value of the complement fixation test in diagnosis. These deficiencies should be remedied in the next edition and an index should be added to the bibliography to enhance the value of this useful monograph.

T.C.M.

\section{REGIONAL ILEITIS}

By Burrill B. Crohn, M.D. Pp. viii +229 , with 74 illustrations. London: Staples Press Ltd. I 950. 3os.

In 1932 Crohn and his collaborators first described regional ileitis as an entity. Since then he has continued to study the disease in all its clinical 
and anatomical forms and has steadily followed his cases in order to build up a complete picture of this perplexing disease. The result of his work has now been published in an excellent monograph based on a detailed study of 300 personal cases, together with a review of the literature, including 257 references.

Regional ileitis has now extended far beyond the limited concept of 1932 and in this work Crohn defines four separate types each with its own pathological pattern and surgical problems. The clinical descriptions are good and well illustrated. The advice on the management of cases is clear and based on wide experience and a thorough knowledge of the natural hisiory of the disease. The purely pathological aspects are less detailed: the descriptions of the naked eye lesions are rather brief and the references to the histological findings are scanty.

The author has carefully reviewed the various aetiological factors that have been suggested, but in spite of a great deal of thorough clinical investigation the aetiology and pathogenesis remain as elusive as ever.

The book is admirably printed and the only errors noted were Langerhans for Langhans on pp. $4 \mathrm{r}$ and 44 and misprints on pp. 12 and 18 .

It is cordinally recommended to anyone, surgeon or physician, interested in the diagnosis or management of regional ilietis.

\section{THE ABC OF ACID-BASE CHEEMISTRY}

By Horace W. Davenport. 3rd Edition. Pp. 86. Chicago: The University of Chicago Press. 1950. \$2.

The contents range over a fairly large field, beginning with the comparatively simple partial pressure of a gas and composition of alveolar air, passing through the carriage of oxygen in blood with buffer action and haemoglobin as a buffer, the carriage of carbon dioxide and its partition in plasma and whole blood, to the distribution of ions between plasma and whole blood. The last sections deal with the chemical regulation of respiration with respiratory alkalosis and acidosis and metabolic acidosis. Under these headings there are many difficult corsceptions and calculations to be considered and overcome. Each section is clearly described. The great value to the student is the actual working out of examples in every case. The author believes a student fresh to the subject can master it in 14 days; this will certainly require his whole time and effort. The ordinary courses in the student's career at a medical school only touch the fringe and, with the little time available, his knowledge cannot be significant, so that the book must be of value to those taking up the subject in this country.

The book is in itself a postgraduate course and is thoroughly recommended. The only criticism is the paper cover, which is not strong enough to stand daily use. The printing is clear, the equations well spaced and curves well drawn and reproduced.
INTRODUCTION TO PUBLIC HEALTH LAW

By John J. Clakke, M.A., F.S.S. Pp. 138. London: Cleaver-Hume Press Ltd. 1950. I2s. $6 \mathrm{~d}$.

This book is intended as a companion to the author's Introduction to Planning Law, and fulfils the expectations which his name arouses. His aim of providing ' a succinct guide to the provisions of the principal Acts treated' is successfully attained, although the law of housing is not dealt with. The introductory chapters deal briefly with the development of public health legislation during the last hundred years, and explain the administrative framework of local government and its relation to the judicial system. The succeeding chapters set out the law as it applies to various subjects, such as Sewerage and Sewage Disposal, Removal of Refuse and Cleansing, etc., so as to make it easy to ascertain what are the enactments and provisions relating to a particular matter under consideration. It has been used in a large public health department and it can be thoroughly recommended as a practical book of reference. Students should find in it a lucid explanation of much which is not readily understood by them, and a valuable guide long after the examination ordeal is over.

\section{AVIATION MEDICINE. ITS THEORY AND} APPLICATION

By KenNeth G. Bergin, M.A., M.D., D.P.H., A.F.R.Ae.S. Pp. xvi +447 , with 120 illustrations. Bristol : John Wright \& Sons. 1949. 35 s.

It is difficult to ascertain for which section of the medical profession this book has been written. While serving to introduce the general practitioner to this branch of medicine, it fails somewhat to guide his further studies. It is particularly regretted that the text is not indexed with bibliographical references, particularly where original text would appear to have been used. There are instances where the references do not appear to have a bearing upon the chapter matter. Many original and classical bibliographical references are not included. In consequence it loses much of its potential value to medical students. For those engaged in Aviation Medicine in the Services it does little to augment the publications already available to these medical officers. In claiming to cover for the first time such a wide range of subject matter, it is felt that the author has been somewhat ambitious and it is doubtful whether the attempt is justified in the light of the comprehensive and authoritative works of Armstrong, Ross Macfarland, Fulton and others.

The quality of paper, printing and illustrations throughout this book are of a high standard and do much to make it warrant its advertised readable qualities. 